KRZYSZTOF KOPCZYŃSKI

Institute of Applied Polish Studies

University of Warsaw

\title{
Religious and quasi-religious attitudes in four Polish documentaries from 2008-2019
}

\begin{abstract}
Kopczyński Krzysztof, Religious and quasi-religious attitudes in four Polish documentaries from 2008-2019. "Images" vol. XXX, no. 39. Poznań 2021. Adam Mickiewicz University Press. Pp. 139-155. ISSN 1731-450X. DOI 10.14746/i.2021.39.07.

The paper aims to present different ways of showing religious and quasi-religious attitudes in contemporary Polish documentaries. The discussion is based on four feature-length films: Kites by Beata Dzianowicz (2008), Communion by Anna Zamecka (2016), Who Will Write Our History by Roberta Grossman (2018), and Tell No One by Tomasz Sekielski (2019). The author evaluates the methodological usefulness of reflection in the documentary of the "religious film" category used in Polish research and the concept of "transcendent(al) style" taken from Paul Schrader's book. Occasionally touching upon the question of the relationship with audiences, the author also mentions the paradigm of Polish Romanticism present in contemporary culture.
\end{abstract}

KEYwORDS: Polish film, documentary, religious film, transcendental style, transcendent style, Romanticism, paradigm of Romanticism, religion in film, Roberta Grossman, Who Will Write Our History, Beata Dzianowicz, Kites, Anna Zamecka, Communion, Tomasz Sekielski, Tell No One

The paper aims to show different ways of presenting religious and quasi-religious attitudes in contemporary Polish documentaries. The discussion will be based on four feature-length films: Kites by Beata Dzianowicz (2008), Communion by Anna Zamecka (2016), Who Will Write Our History by Roberta Grossman (2018), and Tell No One by Tomasz Sekielski (2019). These projects represent different types of filmmaking craft and different principal modes of documentary filmmaking according to Nichols' classic typology: poetic, expository, observational, participatory, reflexive, and performative.[1] The purpose of the paper is to show selected aspects of the phenomenon rather than to build generalisations.

Research on religious films in 21st-century Poland is represented by authors such as Mariola Marczak (2000), Tomasz Kłys (2005), the Rev. Marek Lis (2007, 2011), Krzysztof Kornacki (2002, 2013), Mirosław Przylipiak (2002, 2015), Agnieszka Morstin-Popławska (2010), Magdalena Kempna-Pieniążek (2013), and Marta Stańczak (2016). Apart from Przylipiak, they give only minimal consideration to documentaries. Nevertheless, I take their research into account when evaluating the
Images

vol. XXX/no. 39

Poznań 2021

ISSN 1731-45OX

\section{The aim of the paper}

[1] B. Nichols, Introduction to Documentary, Indiana-

polis 2010, p. 31-32. 
methodological usefulness of the "religious film" and "transcendent(al) style" categories for thinking about the documentary. I also occasionally touch upon the issue of the relationship with audiences, which some of the aforementioned authors have found interesting.

The religious documentary

Defining the notion of a "religious film", the authors of the monumental Światowa encyklopedia filmu religijnego [World Encyclopaedia of Religious Film], published in Poland in 2007, took into account:

1. films on biblical themes;

2. adaptations of works of literature widely considered religious;

3. film hagiographies and biographies of people important to particular religions or denominations;

4. films about people who devoted their lives to God and serving others;

5. films whose makers wrestle in various ways with the requirements of morality determined by religion;

6. films of 'hidden religiousness', the analysis of which enables deep spiritual or metaphysical meanings to be noticed;

7. selected films which superficially exploit religious themes (death, the afterlife, hell etc.), but are identified as religious by many viewers.[2]

The encyclopaedia's editors decided against including "films whose lifespan and territorial reach have been very limited" and films, especially documentaries, "whose distribution has been limited to closed audience groups". Given the lack of in-depth research on the Polish documentary market[3] and the poor availability of analyses of other documentary markets, the practical application of all the aforementioned criteria for documentaries has to be difficult.

The Rev. Andrzej Luter, a critic, would rather call Lis and Garbicz's publication an Encyclopaedia of Films with Religious Motifs. In his opinion, it is impossible to say what makes a film Christian, Catholic, or religious. "There are films which - through the existential dilemmas of a specific character and his or her spiritual choices - touch on the transcendent. And these are the films that speak most strongly to audiences: there is no ideology in them, no traces of religious indoctrination", he argues.[4] The author does not take a stance on Mariola Marczak's ideas from her book on the poetics of religious films, [5] nor on Tomasz Kłys's argumentation introducing his own typology.[6]

[2] Światowa encyklopedia filmu religijnego, eds.

M. Lis, A. Garbicz, Kraków 2007, p. 8.

[3] K. Kopczyński, Nowe tendencje w dystrybucji filmów dokumentalnych $w$ Polsce końca II dekady XXI wieku, [in:] Dystrybucja filmowa. Od kina do streamingu, eds. S. Rogowski, A. Wróblewska, Warszawa 2020, pp. 117-119.

[4] A. Luter, Poszukiwanie transcendencji w kinie polskim dwudziestego pierwszego wieku, „Ethos” 2010, no. 1, p. 139.
[5] M. Marczak, Poetyka filmu religijnego, Kraków 2000, pp. 11-19.

[6] T. Kłys, Filmy (nie)religijne, [in:] Między słowem a obrazem: ksiega pamiatkowa dla uczczenia jubileuszu profesor Eweliny Nurczyńskiej-Fidelskiej, eds.

M. Jakubowska, T. Kłys, B. Stolarska, Kraków 2005, p. 176-192. 
Paul Coates is not keen on the category of "religious film", either, beginning his thoughts on "The Religious Film': a Genre?" by invoking Monty Python's Life of Brian (1979). Pointing out the widespread institutional affiliation of religious films, he distinguishes "between 'religion' and 'spirituality', with the former involving the institutional codification and transmission of beliefs, the latter being more loosely-defined, independent, even individualistic." [7] Spirituality in the latest cinematic productions is the focus of Kempna-Pieniążek's book, in which religious films play a greater role than is suggested by the whole chapter devoted to them. The author mainly analyses non-Polish narrative feature films, but she also considers Philip Gröning's Into Great Silence (2005), an obvious example of a religious documentary in European cinema.[8]

In an article published four years after the encyclopaedia was released, the Rev. Lis wrote: "Religious themes are becoming noticeable in Polish documentaries, but so far few film experts or historians (and theologians) of cinema have decided to study this area of filmmaking. Religiousness has thus become a doubly undescribed reality: by the lack of its film images and their film-studies analyses." [9] However, a different picture emerges from the volume Historia polskiego filmu dokumentalnego (1945-2014) [The History of Polish Documentary Film (1945-2014)]. In the monograph's chapter entitled "Religious films" which discusses the 1990s, Mirosław Przylipiak assumes that religious documentaries are "all films centred around people connected with religion (priests, believers) and/or religious institutions and rituals, and also films intentionally expressing a religious worldview." [10] The author cites more than 60 films fulfilling these requirements. He also polemicises with the Rev. Lis, who estimated the number of Polish documentaries about John Paul II at over 100, additionally accusing most of them of being hagiographic. Przylipiak points out that several dozen such films were produced in the 199 os alone. For precision's sake, let us note that the "religious films" category is not distinguished in the part of the monograph discussing the period after 2000, although documentaries about John Paul II are represented there.[11]

In the introduction to the encyclopaedia, the Rev. Lis noted that studies on religious themes in film were not well-developed in Poland, but "things are much better in Western European countries and in the United States." [12] Ten years later, Bartosz Wieczorek spoke of a "theological turn" in Polish research on film, referencing the Rev.

[7] P. Coates, Cinema, Religion and the Romantic Legacy, Aldershot, Burlington 2003, pp. 7-8.

[8] M. Kempna-Pieniążek, Formuły duchowości $w$ kinie najnowszym, Katowice 2013, pp. 79-82. [9] M. Lis, „Przed i po „Dekalogu”. Spojrzenie na polska religijność, [in:] Zobaczyć siebie. Polski film dokumentalny przełomu wieków, eds. M. Jazdon,
K. Mąka-Malatyńska, Poznań 2011, pp. 51-52. [10] M. Przylipiak, Filmy religijne, [in:] Historia polskiego filmu dokumentalnego (1945-2014), ed. M. Hendrykowska, Poznań 2015, p. 542.

[11] Ibidem, pp. 660-661, 674.

[12] Światowa encyklopedia filmu religijnego..., p. 8. 
Lis and Mariola Marczak, as well as adding a footnote citing six projects[13] which, he believed, testified to the "dynamic development" of such studies globally.[14]

Wieczorek underlines the great importance of theology in film criticism. In his view, without it, our understanding of a film may be "theologically erroneous" as well as shallow and short-lived. "Interpreting a given film in locus theologicus terms thus requires specific competences. Today one can find many crypto-religious, anti-religious films that try to use religious rhetoric, films that use religious narration to undermine religion itself, and films pretending to be religious but presenting the opposite values". The theologian critic thus defends religious films against this trend. Only such a person can tell whether God is speaking to humankind through a particular film.[15]

It is worth noting that over the past 30 years, the category of religious documentaries has been absent from the output of authors whom I would count as part of the mainstream of global reflection on the documentary film, including scholars such as Ian Aitken (2006), Eric Barnouw (1993), Richard M. Barsam (1993), Jack C. Ellis and Betsy A. McLane (2011), Bill Nichols (2010), and Michael Renov (1993). Even if mentioned, religious themes, presentations of people's religious stances, and the history of religion are not brought up as elements of methodological proposals.

For the filmmakers of the documentaries I have selected, religion remains an important, albeit ambiguous, point of reference, thanks to the protagonists' attitudes related to religion. The question is, are there grounds to distinguish such documentaries, or even just the themes, scenes or sequences they contain, using criteria of the filmmaking craft, in particular those related to style?

The transcendent(al) style in documentaries
As we know, Paul Schrader used the term "transcendent(al) style" to analyse the works of Ozu, Bresson, and Dreyer. However, he noted that it was applicable to the output of many film directors from many countries who show a need to reconcile two universal possibilities: expressing Transcendence in art and taking advantage of the film medium's nature. Schrader, who moved from film theory to practice shortly after the publication of Transcendental Style in Film (1972), was aware of the difficulty of pursuing such a goal, but also that it was largely inevitable that filmmakers who treated film as an art would want to pursue it. Then again, he claimed that "many filmmakers have employed
[13] C. Deacy, Faith in Film: Religious Themes in Contemporary Cinema, London, New York 2005; J. Lyden, Film as Religion: Myths, Morals, and Rituals, New York 2003; C. Marsh, Theology Goes to the Movies: An Introduction to Critical Christian Thinking, New York 2007; C. Deacy, G.W. Ortiz, Theology and Film: Challenging the Sacred/Secular Divide, Malden, Oxford, Victoria 2009; G. Lynch, Understanding The- ology and Popular Culture, Malden, Oxford, Victoria 2004; C. Deacy, Screen Christologies. Redemption and the Medium of Film, Cardiff 2001.

[14] B. Wieczorek, Wstęp, [in:] Teologia i film. Perspektywy badawcze, ed. B. Wieczorek, Kraków 2017, pp. 5, 7-8.

[15] Ibidem. 
the transcendental style, but few have had the devotion, the rigour, and the outright fanaticism to employ it exclusively." [16]

Schrader states clearly that transcendent(al) style and religious style, which he treats as a separate category, are not the only ones through which art can attain the Transcendent. Transcendence is understood differently in different cases, but it is reached via parallel and similar paths.

Semantically, transcendental style is simply this: a general representative filmic form which expresses the Transcendent. [...] transcendental style refers to a specific filmic form, although there could conceivably be several transcendental styles in film. [...] The study of transcendental style reveals a 'universal form of representation'. That form is remarkably unified: the common expression of the Transcendent in motion pictures.[17]

The author takes advantage of Jacques Maritain's proposed division into abundant and sparse means, showing that by moving towards the Transcendent, film travels the distance from the former means to the latter. He also claims that religious films are the most frequent examples of the overuse of the abundant artistic means. Finally, he admits that though they have universal value, Maritain's terms are extremely difficult to apply to specific films. [18]

In its desirable variant, "transcendental style seeks to maximise the mystery of existence; it eschews all conventional interpretations of reality: realism, naturalism, psychologism, romanticism, expressionism, impressionism, and, finally, rationalism". It should transport the viewer from the familiar world to the other world "through the trials of experience to the expression of the Transcendent; it can return him to experience from a calm region untouched by the vagaries of emotion or personality". To Schrader, the greatest enemy of transcendence is immanence, which he notices in realism, rationalism, psychologism and expressionism. As he writes, "To the transcendental artist these conventional interpretations of reality are emotional and rational constructs devised by man to dilute or explain away the transcendental." [19]

Attentive analysts of Schrader's argumentation have noticed that when he writes about transcendental style, what he actually means is transcendent style.[20] In the only case I know of this concept being applied to a documentary, it is called transcendent style; I refer to Mirosław Przylipiak's analysis of Wojciech Starońs film El Misionero (2000). Interestingly, after discussing a few dozen religious documentaries, the author finds that only this one film, about a Polish missionary working in the Andes, is compatible with Schrader's ideas, the deciding factors being the cinematography and how other cinematic means are used. Przylipiak believes that El Misionero might also be included among films showing in-depth, universal existential reflection. To him,

[16] P. Schrader, Transcendental Style In Film: Ozu, Bresson, Dreyer, Berkeley - Los Angeles - London 1972, p. 9.

[17] Ibidem, pp. 7-8, 9 .
[18] Ibidem, p. 162.

[19] Ibidem, pp. 159, 169, 10. [20] Światowa encyklopedia filmu religijnego..., p. $482-483$. 
this is proof of the arbitrary nature of the division into genres, in which he comes close to the Rev. Luter's view mentioned earlier.[21]

Przylipiak already considered transcendence in documentaries in his book Poetyka kina dokumentalnego [The Poetics of Documentary Cinema]. To him, this transcendence is not necessarily religious; it involves stepping over the horizon of ordinariness and having the ability to go beyond oneself. Documentary filmmaking that deserves to be called art shows that which is visible and incorporates that which is invisible. It respects mystery, but provides inspiration for overstepping reality.[22]

Meanwhile, invoking Kant directly and diverging slightly from Schrader, one can assume that the opposition of the transcendent would be the empirical. This makes it easier to consider the documentary filmmaking craft. In the common awareness, the documentary lies within the realm of experience, which is clearly related to all the functions that Michael Renov sees as driving documentary discourse: "to record, reveal, or preserve; to persuade or promote; to analyse or interrogate; to express." [23] Even if we enhance this list with a category important for the relationship with audiences - "to recover" - a documentary filmmaker aspiring to the transcendent(al) style will only stand a chance if this opposition is abolished, i.e. if we acknowledge that the camera encroaching upon reality, and also other tools supplementing its work, can find the transcendent in the experience of the everyday, or, in particular cases, in restoring the viewers' experience to them, which they might then start seeing differently. In other words, the function of the documentary has to be stripped of any univocity, in rejection of assertions that "tend to cast nonfiction films in a single role, that of deceptive representations." [24]

Even though Schrader - mistakenly, in my view - includes romanticism among the "conventional interpretations of reality", the paradigm of Romanticism can actually offer some inspiring means for interpreting religious attitudes in film. In Poland, it continues to be a source of symbolic elements in the arts and in everyday behaviours. In English-language writing, it has been used in the analysis of films in a religious context by Coates. [25]

Among other things, the paradigm of Romanticism covers epistemological courage in overstepping boundaries. This is based on a belief in the spiritual nature of the world, whose qualities are the easier to reveal, the simpler and more sensitive is the relationship between the observer and the world, and the greater the distancing from institutional patterns. This is an attitude embraced by many documentary filmmakers.

[21] M. Przylipiak, Filmy religijne..., p. 546-547. [22] Idem, Poetyka kina dokumentalnego, Gdańsk Słupsk 2004, p. 332.

[23] M. Renov, Towards a Poetics of Documentary, [in:] Theorizing Documentary, ed. M. Renov, New York - London 1993, pp. 21-22.
[24] C. Plantinga, Moving pictures and the rhetoric of nonfiction film: two approaches, [in:] Post-Theory: Reconstructing Film Studies, eds. D. Bordwell, N. Carroll. Madison, WI, 1996, p. 308.

[25] P. Coates, op.cit. 
As if upon a sign from above (Who Will Write Our History, dir. Roberta Grossman, 2018)

Who Will Write Our History is a monumental project, a histordocumentaries ical fictionalised documentary loosely based on Samuel D. Kassow's book of the same title. It tells the story of the Ringelblum Archive, one of the most important sources for research on the Holocaust. For the purpose of gathering documentation, Dr Emanuel Ringelblum formed a secret organisation in the Warsaw Ghetto: Oyneg Shabes, numbering 60 members. Only three of them survived World War II, including Rachel Auerbach, on whose narrative the film is based.

The documentary combines dramatisations (Ringelblum is played by Piotr Głowacki, with the voice of Adrien Brody) with documentary footage, as well as archival film and photographic materials. It meets the criteria for a Polish production, even though the producer and director, Roberta Grossman, and the main executive producer, Nancy Spielberg, are American. It was screened at Jewish film festivals and in cinemas in the United States; it was also shown in cinemas in other countries and had a special screening at the Berlinale.

Who Will Write Our History chronicles facts, but it also poses some historiosophical questions: about the source of crime, and the sense and methods of remembrance. To the members of Oyneg Shabes, the most important value for which they risked their lives was the documentation of events for those who would not be able to believe them. The film shows a variety of attitudes - including religious ones - in the face of inevitable death. The dramatised parts of the documentary include scenes of prayer and a yeshiva meeting. Orthodox Jews are also present in the archival materials, most of which were produced by German propaganda crews.

Rabbi Shimon Huberband was among those taking part in the work of Oyneg Shabes. It is mainly to him that we owe the documentation of religious life in the ghetto. It was very hard to follow religious laws at the time; there was no ritual slaughter, no meat or milk. The rabbi cited the example of a married couple who wanted to celebrate the feast of Pesach. The wife ate nothing because there was no matzah. The husband ate bread to stay alive. They did not sit down at the table together to celebrate the holiday.

Huberband noted that people treated the commandments more loosely in the ghetto and did not seek advice from the rabbis. There was nothing to ask the rabbis about, and their role diminished. Hersz Wasser wrote in his diary that the history of the Jews was not the history of rabbis, but of the whole nation. Rachel Auerbach, who was not religious, wrote that the closing of the ghetto occurred "as if upon a sign from above". Meanwhile, at one point, Abraham Levin changed the language of his diary from Yiddish to Hebrew, as if wanting to lend his notes biblical significance.

The way religious Jews appear and disappear in the history of the ghetto's liquidation is related to the problem of theodicy. This was a time 
when the existence and role of God was easy to question, alongside the significance of historiosophical interpretations of his actions and the axioms of faith, such as messianism. According to Marek Edelman, Jewish believers abandoned their holy books and proceeded straight towards the Holocaust. Nothing was left of them.

God let them down. He was punishing them for nothing. And so they turned away from God; they shaved off their beards, took off their gaberdines, left the synagogues. [...] Religion went away... All those tall stories people tell, that when the uprising began the Jews prayed, they're just nice literary pieces.[26]

In formal terms, Grossman's documentary is a compilation of the expository and performative modes. On the basis of extensive research and consultations, it presents knowledge while taking care to maintain objectivism and historical correctness (the role of Polish shmaltsovniks [blackmailers], Jewish policemen, and the West's passivity are described with equal condemnation). This knowledge is supplemented with images contained in well-shot dramatised scenes and those put together from archival materials. The credibility of the latter could be questioned if one unceasingly paid attention to the propaganda bias of the archival footage. However, this is something the viewer does not constantly think about, or might even be unaware of. On the contrary, the editing in this case is absolutely in keeping with the requirements of transcendent(al) style: these materials show death - the film's main theme - directly.

The documentary does not explain why everything that happened, happened, because this is beyond its available cognition, and probably beyond cognition as such. In the ghetto, believing in God was just as abstract a utopia as believing that running an open kitchen would save lives. The archivists' motivation to work was provided by their Romantic fidelity to lost causes, shown without any tall tales or aestheticisation. Viewers are left only with remembrance and respect for the people thanks to whom it endured.

Ethnographic helplessness (Kites, dir. Beata Dzianowicz, 20o8)

Kites is an ethnographic documentary, observational and participatory, about a documentary filmmaking course run by Polish filmmakers at the Art and Music School in Kabul in 2006. It describes the reality of a religious state in which Islam determines the everyday behaviours of residents irrespective of their education and experience. It won the Critics' Week contest at the Locarno festival and has been presented in over 20 countries, winning numerous awards, including in Muslim states.

The film starts with a school assembly at which the Quran is read. Then, the students are handed cameras. This is the first time they have

[26] W. Bereś, K. Burnetko, Marek Edelman. Życie. Po

prostu, Warszawa 2008, p. 74. 
ever handled a camera, but they quickly get the hang of it. They carry out one of their first cinematographic tasks on a windy hill, where Kabul's youngsters fight by cutting down one another's kites. Flying kites was banned by the Taliban, just like all forms of depicting human beings. For the students, the footage they shoot on the hill thus has the aspect of being a double overstepping of a religiously motivated ban, the violation of which the Taliban punished by death.

One long shot taken from above captures an explosion. Black smoke slowly floats above the city. What actually happened is shown in the 4.5-minute film Otchłań [Abyss][27] - one of several student documentaries whose fragments have been incorporated into Kites. The filmmakers in this case were Ali Korosh and Mohammed Ali, two 18-year-old participants in the course. Their film is what we would call a spontaneous observational documentary, which is an immediate response to an event and is different from a reportage in its usually less objective camera viewpoint and the use of supplementary footage shot at a later time.

Ali and Mohammed discontinued their exercise on the hill when they noticed a funeral taking place down below. It turned out to be the burial of a woman who had been killed in the bomb explosion. The students were given permission to film during the ceremony. After shooting the funeral, they went to the scene of the crime. They also decided to conduct an interview with the murdered woman's son. They arranged to meet him on the fifth day after the funeral - the earliest possible time, since four days is the time of strict mourning in the Muslim religion. They took the first question they asked - about the happiest day in the interviewee's life - from a street survey that all the course participants conducted.

The film has multiple religious dimensions. A bomb planted in the name of God on Friday, the holy day, killed the protagonist's mother and 15 other people. The funeral is held according to the rules of Islam. A beggar present at the burial asks for help in the name of God for a Muslim brother, and not simply a brother. There are no women present, of course. On the other hand, the son takes part in the ceremony wearing a black shirt, not traditional clothes. And, most importantly, one of the people at the funeral says boldly to the camera that the Taliban's activities run contrary to Islam. This lends extra power to the concluding statement of the son, who recalls his mother teaching him that religion does not allow people to despair at death.

The student exercise shows the documentary filmmakers' ability to respond spontaneously to the - unquestionably transcendent - call of reality, at the same time showing their courage in presenting views that are hard for their native audience to accept. Moreover, Abyss plays a particularly important role in the structure of Kites - a film showing

[27] <https://vimeo.com/372213852/8db21886ff>, accessed 5.12.2020. Original technical version edited with students in Kabul in the Dari language; Polish subtitles. 
the impossibility of communication between filmmakers from Europe and young people brought up in the Central Asian culture of Islam, in a country where violating religious rules can still be punishable by death, even though the Taliban have been ousted from power. Abyss increases the believability of the danger involved. It is about crime in its purest form, because the murdered woman had done the Taliban no wrong. It tells its story in an unmediated way, showing an event taking place in the film's actual time and space. In Kites, this effect is enhanced by the explosion, an event that was filmed by accident. In this part of the film, we move away from the observational mode towards the participatory mode.

Abyss is a religious film in the sense of the definitions discussed earlier, whereas Kites shows that the reality not readily accessible to the European camera also has a religious aspect that Muslims find hard to cope with. It is not enough to be reconciled to death, which also appears in the film in other situations and which is commonplace in Afghanistan. The film's director rejects the easy explanation for attitudes, i.e. invoking the rules of Islam, something that viewers used to European axiology might want. Thus, although they expected a clarified image, they will leave the cinema in a state of performative confusion.

Fragility of bonds of trust (Communion, dir. Anna Zamecka, 2016)

Communion is a participatory documentary, no different from a fiction film in terms of filmmaking craft. It tells the true story of 14-year-old Ola, who takes care of her 13-year-old autistic brother Nikodem as he prepares for his First Communion in provincial Poland. They both live with their alcoholic father. Their mother has left them and now has a child with another man. The First Communion is meant to offer a chance for her return, which is Ola's dream. The film won awards at the Warsaw Film Festival and in the Locarno Critics' Week, received a European Film Award and a Polish Film Award, and was also short-listed for an Academy Award.

Communion draws its strength from the protagonist's relationship with the world. Fighting for her family, Ola becomes a Romantic child who sees more than the adults around her. And although the things she experiences are very painful sometimes, thanks to love she is the one who finds a way to get through to her disabled brother and to influence her father, even though both of them exist outside the boundaries of so-called normalcy. The camera focuses on her; especially closeup shots turn her into a strong character whose face expresses emotions better than would have been made possible by abundant film means.

The father and the brother compete for the role of her main antagonist. The film's director called the latter a prophet in the film's development, introducing a metaphysical element into the story[28].

[28] B. Czyżewska, Rodzina, której nie ma, "Vogue" 2019, 3.02, <https://www.vogue.pl/a/rodzina-ktorejnie-ma>, accessed: 6.12.2020. 
In fact, he does offer some aphorisms, e.g. "reality becomes fiction". $\mathrm{He}$ is also able to defend what he believes in. Risking that the priest, whom his sister calls "mean", will refuse to allow him to have his First Communion, he insists to the very end that the theological virtues are faith, hope, and gluttony.

The communion ceremony is shown in an ambiguous way in the film. Its formal importance seems to dominate strongly over the religious. It is of fundamental importance in the story's structure, as it gives Ola a chance to move a step forward in her plan to reunite the family, since the mother decides to take part in the celebration. We learn from the director that it was thanks to her efforts that the priest finally decided to allow Nikodem to receive communion[29].

The love that rules in the world represented in this documentary turns out to be independent of religion; it has a separate and powerful status. There is a reason why the Buddhist monks to whom Zamecka presented her film in Japan asked about the role of religion in Ola's daily life. On the other hand, no such questions are asked of her in Europe, which she finds surprising[30]. Perhaps it is because of something noticed by S. Brent Plate, author of the book Religion and Film: Cinema and Re-Creation of the World (2008) based on experiences from observing different religions. He wrote that "religion is about bodies, not beliefs." [31] Religion in Europe is more the sphere of beliefs, whereas the Buddhist monks sensed the energy of a body where goodness lived. Actually, everyone is good in the world portrayed in Communion; nobody is accused: not the unruly boy, not the father with his partiality for beer, not the priest who can say "get lost" and make the family lose the money they invested in the ceremony, not even the mother, although she left her children and husband and refuses to return despite her daughter's suffering.

An interpretation that attributes transcendental meaning to the communion presented in the story also seems justifiable. The attitudes of the protagonists - Ola, Nikodem, the father and the mother - can be described in terms of fragility as understood by Levinas and especially Ricoeur, according to whom "the individuality of character, i.e. the limited practical and motivational opening up of the acting subject to the world, undergoes endless extension together with the drive for happiness, whereas in the realm of affectivity, isolated vital feelings open up to the comprehensive, happiness-generating horizon of spiritual feelings. This existential dialectics builds the foundation of the socalled ontology of disproportion, which comes down to human beings' experientially given inherent disproportion, making them emotionally fragile and consequently fallible, imperfect beings." [32] This is the way

[29] Ibidem.

[30] Ibidem.

[31] <http://www.sbrentplate.net/>, accessed 29.11.2020.
[32] R. Grzywacz SJ, Krucha podmiotowość, czyli o sporze na gruncie Lévinasowskiej i Ricœurowskiej filozofii człowieka oraz niektórych jego implikacjach dla rozumienia zdrowia psychicznego, „Logos i Ethos” 
in which Ola feels responsible for the "fragilities" shown in the film: her brother's Christianity, her parents' relationship. It does not matter whether they are genuine or only imagined by her.

According to Ricoeur, the bond of trust woven between "fragility" and "the one responsible" is not created by reason, but comes from deep layers of emotionality. "When we come face to face with the fragile, a feeling of pity and compassion is immediately born. We very clearly feel a call to help, to protect the fragile." [33] Guided by such a premise in the process of absorbing the documentary, viewers might take responsibility for the fragility of which Ola's attitude is also a part. If this happened, it would be up to the viewers to say if the film carries a "hidden religiousness" whose "analysis enables us to notice deep spiritual or metaphysical meanings".

The documentary character of the message strengthens the credibility of the situation and the power of the call to help. The opportunity presented by the First Communion has not worked out, but perhaps a new one will appear in future. Nikodem - a prophet and thus a poet - stands a chance of extracting it from a world in which he plays a privileged epistemological role. Today, from the other side of the screen, we know this will not happen, because the father has since died,[34] but this is of no significance for the immanent interpretation of the work and the expectations of its audience.

Unexpected liberation of truth (Tell No One, dir. Tomasz Sekielski, 2019)

Since its YouTube premiere on 11 May 2019, Tell No One - an investigative documentary dealing with paedophilia in the Roman Catholic Church in Poland - has become probably the most-watched Polish documentary in history, with over 24 million views and a television audience of 2.5 million people (as of 7 December 2020). The film received a Polish Film Award and several other awards, although the festival circuit was not the filmmakers' aim. In the case of this project, winning Poland's most important professional film award was of special significance. The voting members of the Polish Film Academy used it to show that they valued the poignant subject matter and the sources found by the filmmakers more than the filmmaking craft itself, which is not of the highest order in Tell No One.

An investigative documentary is participatory by its very nature. Its aim is to get to the hidden truth, and this is also the case with Tell No One. The power of the film lies in the fact that its makers sought out many paedophilia victims, lawyers, and some of the perpetrators,

2019, no. 2 (48), p. 85, DOI: http://dx.doi.org/10.15633/ lie.2786.
[33] A. Karoń, T. Wiścicki, Kruchość życia, odpowiedzialność $i$ więź zaufania. Z Paulem Ricoeurem rozmawiają..., „Więź" 1992, no. 12, p. 40.

[34] B. Czyżewska, op.cit. 
and persuaded them to take part in the project, and also that they have incorporated archival materials. Sekielski sometimes used a hidden camera and recorded sound without his interlocutors' knowledge. He has also included interviews with victims who remain anonymous. He does not hesitate to inform viewers about which Roman Catholic hierarchs in Poland refused to be interviewed.

With some of its narrative solutions and its ambition to influence reality, this documentary mimics the work of Michael Moore (and Sekielski even looks a little like him). However, its structure is that of a journalistic report, in which a cohesive three-part composition is less important than adding consecutive cases of child abuse by priests. The witnesses speak very emotionally about the events. The film's imperfect craftsmanship does not get in the way of viewers' strongly affective reception of the testimonies, which gives the appearance of having been planned with faith that a film can change the world. This is a Tyrtaean documentary in the sense that it bolsters up the victims' courage and puts fear into the perpetrators. It proves the great power of revealing the truth in defiance of the hypocrisy of the state and church hierarchies, the hostility shown by the public, and the indifference of media institutions. It continues the discussion begun by Wojciech Smarzowski's Clergy (2018), a fiction feature about the sins of church hierarchies, including paedophilia. With over 5 million viewers, it was the biggest box office success in Poland in the 21st century, confirming just how powerful the topic Sekielski chose for his documentary is.

A few conclusions stemming from this film shocked Polish audiences. First of all, there was the great extent of the problem and the impunity of the perpetrators, who often took advantage of support from the church authorities and the state's sympathetic silence. Then, there was the insolence, self-assurance, and hypocrisy of some hierarchs and priests, ostentatiously contradicting the laws of the Decalogue. Finally, there was the fact that the guilty group included the Rev. Henryk Jankowski, who had celebrated Mass at the Gdańsk Shipyard during the workers' strike in August 1980, and the Rev. Franciszek Cybula, chaplain of Lech Wałęsa, the leader of Solidarity who was president of Poland in the years 1990-1995. It is worth adding that both these priests had been secret collaborators of the communist Security Service. Wałęsa stated in Sekielski's film that due to his peasant origins, which cast the clergy in the role of an unquestioned authority, he would not have dared to suspect the Rev. Cybula of anything.

Of course, Tell No One is not a religious film, although, paradoxically, it fulfils the requirements of Przylipiak's definition, as well as the Rev. Lis's (item 5). Nor does it contain an attack on religion, though that would not have been surprising. Some of the victims of paedophilia declare themselves to be religious; others say they have lost their faith. As the knowledge about the subject of the documentary investigation 
grows, the viewer is taken further away from the transcendent. From the point of view of the present paper, the people in Sekielski's documentary represent quasi-religious attitudes in their purest form, despite the slightly excessive style applied by the film's director.

In 2020, Tomasz Sekielski made his next documentary on paedophilia committed by clergymen: Playing Hide and Seek. The same year saw broadcasts of Marcin Gutowski's reportages, Don Stanislao: The Other Face of Cardinal Dziwisz and Don Stanislao: Post Scriptum, which focus on the long-time papal secretary. The director of Tell No One has announced plans for a film on the role of John Paul II in the dissimulation of crimes committed by priests and on the Redemptorist Tadeusz Rydzyk, head of Radio Maryja and one of the most influential figures of Poland's political life. A summary of the second decade of the 21st century in Polish film will have to give these investigative documentaries their due place.

Conclusion:

the creative treatment of religious actuality
The discussion so far has aimed to show that an issue of fundamental importance for documentary films - the attitudes of the people they present - can be considered separately from any attempts to classify a documentary in terms of its genre (or sub-genre) and its style. None of the projects outlined above are a "religious film" in the sense of fulfilling the criteria of various definitions of the genre and enabling it to win institutional or - sometimes coinciding - theological approval. "Transcendent(al) style", on the other hand, does not appear as a useful category in reflecting on documentaries, and especially in trying to separate fragments of a film that are devoted to religion from those that are not. The truth is, although they need to have the courage to not always evade stylistic and narrational flaws, documentaries should follow a uniform, coherent style. It might be possible to prove the effectiveness of applying Schrader's concept in the hermeneutics of Into Great Silence, but such an attempt lies outside the area of the present study.

However, this does not mean that Who Will Write Our History, Kites and Communion (Sekielski's investigative documentary being a separate trend) are not evidence of the possibility "to join an experience of the absolute to the idea of the absolute", if we refer to "The Hermeneutics of Testimony." [35] In the first two of the above films, it is the partially or fully religious experience of war and death, and in the third - the experience of a religious rite experienced by a protagonist endowed with an augmented sense of observation. Applying such an interpretative key to Kites and Tell No One additionally implies an ironic-Romantic overturning of the axiology created by institutional representatives of religions committing or at least allowing crime.

[35] P. Ricoeur, Hermeneutyka świadectwa, [in:] idem, Nazwać Boga. Teksty Paula Ricoeura, trans. R. Grzywacz, Kraków 2011, p.15. 
Krzysztof Kieślowski wrote in 1970:

Unlike in literature, where the more of circumstances are unusual and complicated the more the imagination of the reader works, film can count on stimulating the imagination by referring to the audience's own experience. However, for this to happen, the author must rely on his sense of observation. This is usually when a documentary is made.[36]

I think this principle is noticeable in all four films. To increase her film's power as an instrument of cognizance, Roberta Grossman adds dramatisations; Beata Dzianowicz uses the film-within-a-film technique as a means of changing the character of the narrative and the relationship with the viewer; Anna Zamecka influences events. For Tomasz Sekielski, the primary criterion for using specific materials is their factual value. In each of these cases, the audience's own experience mentioned by Kieślowski can be a religious experience on different levels: as a metaphysical attempt to explain the course of history within the Divine logic of history, or only as minimised knowledge on the actions of the clergy of different religions in a world proceeding according to the rules they created.

Leaving a discussion on documentary film as philosophy and as religion for a different occasion, I would like to offer a few words about the question of imagination raised by Kieślowski. If a documentary is to be a "re-creation of the world", it should expect the audience to work their imagination in accordance with the message of Blake and Coleridge, who speak not only of creation and re-creation with the imagination, but also of how it establishes laws that must be respected in this world. Such a model of action is close to the paradigm of Romanticism, especially the part related to epistemology. Art serves ever new cognizance and does not accept its earlier, ineffective instruments. It attains transcendence in a religious sense, but also in an act of creation that is considered heresy, stemming not only from rejecting the old but also searching for a new God, or determining that there is no God. And it is in this sense that the religious and quasi-religious attitudes shown in the four films discussed here justify considering each of them as a documentary that is a Griersonian creative treatment of (religious) actuality.

Aitken I. (ed.), Encyclopedia of the Documentary Film, vol. 1, New York - London 2006

Barnouw E., Documentary: A History of the non-fiction film, New York - Oxford 1993

Barsam R.M., Nonfiction Film: A critical history revised and expanded, Indianapolis 1992

[36] Theory of Practice: Kieślowski, Łoziński,

Wiszniewski, Królikiewicz, Żebrowski, ed. K. Mą-

ka-Malatyńska, Łódź 2019, p. 14. 
Bereś W., Burnetko K., Marek Edelman. Życie. Po prostu, Warszawa 2008

Coates P., Cinema, Religion and the Romantic Legacy, Burlington 2003

Czyżewska B., Rodzina, której nie ma, "Vogue" 2019, 3.02, <https://www.vogue. $\mathrm{pl} / \mathrm{a} /$ rodzina-ktorej-nie-ma>, accessed 6.12.2020

Deacy Ch., Ortiz W., Gaye, Theology and Film: Challenging the sacred/secular divide, Oxford 2008

Ellis J.C., McLane B.A., A New History of Documentary Film, New York - London 2011

Grzywacz R. SJ, Krucha podmiotowość, czyli o sporze na gruncie Lévinasowskiej $i$ Ricœurowskiej filozofii człowieka oraz niektórych jego implikacjach dla rozumienia zdrowia psychicznego, „Logos i Ethos” 2018, no. 2 (48), DOI: http:// dx.doi.org/10.15633/lie.2786

Hendrykowska M. (ed.), Historia polskiego filmu dokumentalnego (1945-2014), Poznań 2015

Herzogenrath B. (ed.), Film as Philosophy, Minneapolis 2017

Jazdon M., Mąka-Malatyńska K. (eds.), Zobaczyć siebie. Polski film dokumentalny przełomu wieków, Poznań 2011

Johnson R.K. (ed.), Reframing Theology and Film: New focus for an emerging discipline, Michigan 2007

Kempna-Pieniążek M., Formuły duchowości w kinie najnowszym, Katowice 2013

Kłys T., „Filmy (nie)religijne”. Między słowem a obrazem: księga pamiątkowa dla uczczenia jubileuszu profesor Eweliny Nurczyńskiej-Fidelskiej, eds. M. Jakubowska, T. Kłys, B. Stolarska, Kraków 2005, pp. 176-192

Konefał S.J., Zelent M., Kornacki K. (eds.), Sacrum w kinie dekadę później, Gdańsk 2013

Kopczyński K., Nowe tendencje $w$ dystrybucji filmów dokumentalnych $w$ Polsce końca II dekady XXI wieku", [in:] Dystrybucja filmowa. Od kina do streamingu, eds. S. Rogowski, A. Wróblewska, Warszawa 2020, p. 117-128

Kopczyński K., Paradygmat polskiego romantyzmu w uniwersum filmowym, Kraków 2021

Lis M., Przed i po „Dekalogu”. Spojrzenie na polską religijność, [in:] Zobaczyć siebie. Polski film dokumentalny przełomu wieków, eds. M. Jazdon, K. Mąka-Malatyńska, Poznań 2011, pp. 51-60

Lis M., Garbicz A. (eds.), Światowa encyklopedia filmu religijnego, Kraków 2007

Lute A., Poszukiwanie transcendencji w kinie polskim dwudziestego pierwszego wieku, „Ethos” 2010, no. 1 (89), pp. 139-147

Marczak M., Poetyka filmu religijnego, Kraków 2000

Mąka-Malatyńska K. (ed.), Theory of Practice: Kieślowski, Łoziński, Wiszniewski, Królikiewicz, Żebrowski, Łódź 2019

Morstin-Popławska A., Jak daleko stąd do raju? Religia jako pamięć w polskim filmie fabularnym, Kraków 2010

Nichols B., Introduction to Documentary, Indianapolis 2010

Plantinga C., Moving pictures and the rhetoric of nonfiction film: two approaches, [in:] Post-Theory: Reconstructing film studies, eds. D. Bordwell, N. Carroll. Madison, WI, 1996, pp. 307-324

Plate S.B., Religion and Film: Cinema and re-creation of the world. London - New York 2010

Przylipiak M., Filmy religijne, [in:] Historia polskiego filmu dokumentalnego (19452014), ed. M. Hendrykowska, Poznań 2015, p. 542-546

Przylipiak M., Poetyka kina dokumentalnego, Gdańsk - Słupsk 2004

Przylipiak M., Kornacki K. (eds.), Poszukiwanie i degradowanie sacrum w kinie, Gdańsk 2002

Renov M. (ed.), Theorizing Documentary, New York - London 1993 
Ricoeur P., "Hermeneutyka świadectwa". Nazwać Boga. Teksty Paula Ricoeura, trans. R. Grzywacz, Kraków 2011

Schrader P., Transcendental Style In Film: Ozu, Bresson, Dreyer, Berkeley, Los Angeles - London 1972

Stańczyk M., Doświadczenie transcendencji - współczesne kino religijne, „Kwartalnik Filmowy" 2016, no. 86

Wieczorek B. (ed.), Teologia i film. Perspektywy badawcze, Kraków 2017 